\title{
Pleomorphomonas koreensis sp. nov., a nitrogen-fixing species in the order Rhizobiales
}

Correspondence
Sung-Taik Lee
e_stlee@kaist.ac.kr

\author{
Wan-Taek Im, ${ }^{1}$ Seong-Hye Kim, ${ }^{1}+$ Myung Kyum Kim, ${ }^{1}$ Leonid N. Ten ${ }^{2}$ \\ and Sung-Taik Lee ${ }^{1}$
}

\author{
${ }^{1}$ Environmental and Molecular Microbiology Laboratory, Department of Biological Sciences, \\ Korea Advanced Institute of Science and Technology, 373-1 Guseong-dong, Yuseong-gu, \\ Daejeon 305-701, South Korea \\ ${ }^{2}$ National University of Uzbekistan, Students town, Tashkent, 700-174, Uzbekistan
}

In the most recent edition of Bergey's Manual of Systematic Bacteriology (Garrity \& Holt, 2001), the order Rhizobiales is the biggest group within the $\alpha-2$ subgroup of the Proteobacteria and constitutes a heterogeneous group from both a physiological and an ecological perspective. According to Bergey's Manual, the order Rhizobiales is divided into ten families on the basis of $16 \mathrm{~S}$ rRNA gene phylogenetic analyses: Bartonellaceae, Beijerinckiaceae, Bradyrhizobiaceae, Brucellaceae, Hyphomicrobiaceae, Methylobacteriaceae, Methylocystaceae, Phyllobacteriaceae, Rhizobiaceae and Rhodobiaceae. The order Rhizobiales is characterized chemotaxonomically by its major respiratory ubiquinone (Q-10) and by the presence of octadecenoic acid $\left(\mathrm{C}_{18: 1}\right)$ as a major cellular fatty acid (like other members of the Alphaproteobacteria), and it contains plant and animal pathogens associated with eukaryotic cells (e.g. the families Bartonellaceae and Brucellaceae), plant endosymbionts (Rhizobiaceae), methane-oxidizing bacteria (Methylobacteriaceae and Methylocystaceae) and, in particular, a large number of nitrogen-fixing species (distributed throughout almost all of its families).

tPresent address: Department of Chemical and Biomolecular Engineering, Korea Advanced Institute of Science and Technology, 373-1 Guseong-dong, Yuseong-gu, Daejeon 305-701, South Korea.

The GenBank/EMBL/DDBJ accession number for the 16S rRNA gene sequence of strain $\mathrm{Yg}^{\top}$ is $\mathrm{AB} 127972$.
In this study, a nitrogen-fixing, rod-shaped strain $\left(\mathrm{Y}^{\mathrm{T}}\right)$ was isolated from a contaminated culture of the phototrophic bacterium Rhodopseudomonas palustris. On the basis of $16 \mathrm{~S}$ RNA gene sequence data, strain $\mathrm{Y}^{\mathrm{T}}$ was found to be closely related to Pleomorphomonas oryzae (order Rhizobiales of the Alphaproteobacteria) and was subjected to a taxonomic investigation. The aim of this study was to determine the taxonomic position of strain $\mathrm{Y}^{\mathrm{T}}$ by using chemotaxonomic, physiological and DNA-DNA hybridization analyses. The results provided evidence that $\mathrm{Y} 9^{\mathrm{T}}$ is a representative of a novel bacterial species.

Strain $Y 9^{\mathrm{T}}$ was isolated from a contaminated culture of the phototrophic bacterium $R$. palustris by direct plating on R2A agar (Difco). For analysis of quinones and DNA extraction, cell biomass was obtained from a culture grown in $\mathrm{R} 2 \mathrm{~A}$ broth at $30^{\circ} \mathrm{C}$. Strain $\mathrm{Y}^{\mathrm{T}}$ was cultivated on a horizontal shaker at 150 r.p.m., and the purity was checked using a light microscope prior to harvesting by centrifugation. Unless indicated otherwise, the strain was grown on R2A agar or broth incubated at $30^{\circ} \mathrm{C}$ and maintained as a glycerol suspension $(20 \%, \mathrm{w} / \mathrm{v})$ at $-70{ }^{\circ} \mathrm{C}$.

Cell morphology and motility were observed under a Nikon light microscope $(\times 1000$ magnification $)$ using cells grown for 2 days at $30^{\circ} \mathrm{C}$ on $\mathrm{R} 2 \mathrm{~A}$ agar. The Gram reaction was performed using the non-staining method described by 
Buck (1982). Tests for catalase and oxidase were performed by using the procedures outlined by Cappuccino \& Sherman (2002). Growth at various temperatures $(4,15,25,30,37$ and $42{ }^{\circ} \mathrm{C}$ ) was investigated on R2A agar. Growth at $30^{\circ} \mathrm{C}$ on nutrient agar, trypticase soy agar and MacConkey agar was also examined. Utilization of various substrates as sole carbon sources was investigated, together with some physiological characteristics, using the API $32 \mathrm{GN}$ and API $20 \mathrm{NE}$ galleries according to the instructions of the manufacturer (bioMérieux).

Nitrogen-fixing ability was determined by growing strain $\mathrm{Y}^{\mathrm{T}}$ in $50 \mathrm{ml}$ nitrogen-free medium (DSMZ medium no. 3; Deutsche Sammlung von Mikroorganismen und Zellkulturen) contained in a $125 \mathrm{ml}$ serum bottle. The medium contained the following (in 11 distilled water): $5.0 \mathrm{~g}$ glucose, $5 \cdot 0 \mathrm{~g}$ mannitol, $0 \cdot 1 \mathrm{~g} \mathrm{CaCl} 2.2 \mathrm{H}_{2} \mathrm{O}, 0 \cdot 1 \mathrm{~g}$ $\mathrm{MgSO}_{4} .7 \mathrm{H}_{2} \mathrm{O}, 5.0 \mathrm{mg} \mathrm{Na} \mathrm{MoO}_{4} \cdot 2 \mathrm{H}_{2} \mathrm{O}, 0.9 \mathrm{~g} \mathrm{~K}_{2} \mathrm{HPO}_{4}$, $0 \cdot 1 \mathrm{~g} \mathrm{KH}_{2} \mathrm{PO}_{4}, 0 \cdot 01 \mathrm{~g} \mathrm{FeSO}_{4} .7 \mathrm{H}_{2} \mathrm{O}, 5 \cdot 0 \mathrm{~g} \mathrm{CaCO}_{3}$ and $1 \mathrm{ml}$ trace element mixture. The trace element mixture (SL-6, in DSMZ medium no. 27) contained the following $\left(1^{-1}\right.$ distilled water): $0.1 \mathrm{~g} \mathrm{ZnSO}_{4} .7 \mathrm{H}_{2} \mathrm{O}, 0.03 \mathrm{~g} \mathrm{MnCl}_{2} .4 \mathrm{H}_{2} \mathrm{O}$, $0.3 \mathrm{~g} \mathrm{H}_{3} \mathrm{BO}_{3}, 0.2 \mathrm{~g} \mathrm{CoCl}_{2} .6 \mathrm{H}_{2} \mathrm{O}, 0.01 \mathrm{~g} \mathrm{CuCl}_{2} .2 \mathrm{H}_{2} \mathrm{O}$ and $0.02 \mathrm{~g} \mathrm{NiCl} \cdot 6 \mathrm{H}_{2} \mathrm{O}$. Acetylene reduction was performed for all liquid cultures by injecting purified acetylene into appropriate containers closed with rubber stoppers to yield $15 \%$ acetylene $(\mathrm{v} / \mathrm{v})$; this was followed by incubation for up to $24 \mathrm{~h}$. Ethylene was measured using a Hewlett Packard 5890A gas chromatograph equipped with a flame-ionization detector and a prepacked column (HayeSep N; Supelco). Additionally, the presence of the nifH gene was determined by a PCR with primers and reaction conditions as described by Poly et al. (2001).

The G $+C$ content of the chromosomal DNA of strain $Y 9^{\mathrm{T}}$ was determined as described by Mesbah et al. (1989), using reversed-phase HPLC. Quinones were extracted from cells grown on nutrient broth (Difco), and analysed as described by Shin et al. (1996), using reversed-phase HPLC. Cellular fatty acids were analysed in organisms grown on trypticase soy agar (Difco) for 2 days. The cellular fatty acids were saponified, methylated and extracted according to the protocol of the Sherlock Microbial Identification System (MIDI). The fatty acids, analysed by GC (6890; Hewlett Packard), were identified using the Microbial Identification software package (Sasser, 1990). DNA-DNA hybridization was performed fluorometrically by using the method of Ezaki et al. (1989), with photobiotin-labelled DNA probes and microdilution wells. Hybridization was performed with five replications for each sample. The highest and lowest values obtained for each sample were excluded and the means of the remaining three values are quoted as DNA relatedness values.

PCR-mediated amplification of the 16S rRNA gene and sequencing of the purified PCR product were carried out according to Kim et al. (2005). The complete 16S rRNA gene sequence was compiled using SeqMan software (DNASTAR). $16 \mathrm{~S}$ rRNA gene sequences of related taxa were obtained from the GenBank database. Multiple alignments were performed using the CLUSTAL X program (Thompson et al., 1997). Gaps were edited in the BioEdit program (Hall, 1999). Evolutionary distances were calculated using the Kimura twoparameter model (Kimura, 1983). The phylogenetic tree was constructed by using a neighbour-joining method (Saitou \& Nei, 1987) and maximum parsimony (Fitch, 1972) in the MEGA 3 program (Kumar et al., 2004), with bootstrap values based on 1000 replications (Felsenstein, 1985).

Strain $\mathrm{Y}^{\mathrm{T}}$ consisted of Gram-negative, non-spore-forming, non-motile rods. The cells were $0 \cdot 3-0 \cdot 5 \mu \mathrm{m}$ in diameter and $1 \cdot 5-3.0 \mu \mathrm{m}$ in length. After 2 days incubation on R2A agar, colonies were smooth, low-convex, circular, translucent, non-shiny and white in colour. Strain $\mathrm{Y} 9^{\mathrm{T}}$ grew at $15-42^{\circ} \mathrm{C}$ on R2A agar but not at $4{ }^{\circ} \mathrm{C}$ or above $45^{\circ} \mathrm{C}$. Strain $\mathrm{Y} 9^{\mathrm{T}}$ was able to reduce acetylene to ethylene at a mean rate of $57 \cdot 5 \mu \mathrm{mol} \mathrm{min}{ }^{-1}$ ( $\mathrm{mg}$ wet weight) ${ }^{-1}$ at an incubation temperature of $30^{\circ} \mathrm{C}$. An internal region of nifH (about $360 \mathrm{bp}$ ) was clearly amplified, and strain $\mathrm{Y}^{\mathrm{T}}$ grew well in a nitrogen-free liquid medium. Other physiological characteristics of strain $\mathrm{Y} 9^{\mathrm{T}}$ are summarized in the species description, and some characteristics that differentiate it from P. oryzae $\mathrm{F}-7^{\mathrm{T}}$ are presented in Table 1 .

The 16S rRNA gene sequence of strain $\mathrm{Y} 9^{\mathrm{T}}$ determined in this study was a continuous stretch of $1417 \mathrm{bp}$. A sequence similarity calculation performed after a neighbour-joining analysis indicated that the closest relative of strain $\mathrm{Y}^{\mathrm{T}}$ was $P$.

Table 1. Characteristics that differentiate strain $Y 9^{\top}$ from P. oryzae $\mathrm{F}-7^{\top}$

Both strains are Gram-negative, non-motile, white-pigmented, rod-shaped bacteria. Both strains exhibit catalase, oxidase, urease and $\beta$-galactosidase activities, fix nitrogen and possess the nifH gene and reduce nitrate to nitrite. Both strains are positive for the assimilation of L-rhamnose, D-glucose, D-mannose, L-arabinose, Dribose, sucrose, D-fructose, inositol, D-mannitol and D-sorbitol and negative for the assimilation of L-alanine, L-histidine, 3-hydroxybutyrate, malonate and itaconate.

\begin{tabular}{|lcc|}
\hline Characteristic & $\begin{array}{c}\text { P. koreensis } \\
\text { Y9 }\end{array}$ & $\begin{array}{c}\text { P. oryzae } \\
\mathbf{F}^{\mathbf{T}} \mathbf{7}^{\mathbf{T}}\end{array}$ \\
\hline Indole production & - & + \\
$\beta$-Glucosidase (aesculin hydrolysis) & + & - \\
Protease (gelatin hydrolysis) & + & - \\
Acid from glucose & - & + \\
Utilization as carbon source & & \\
L-Proline & - & + \\
L-Serine & - & + \\
Acetate & - & + \\
Malate & - & + \\
D-Maltose & + & - \\
Gluconate & - & + \\
DNA G+C content $($ mol $\%)$ & $65 \cdot 1$ & $63 \cdot 1$ \\
& & \\
\hline
\end{tabular}




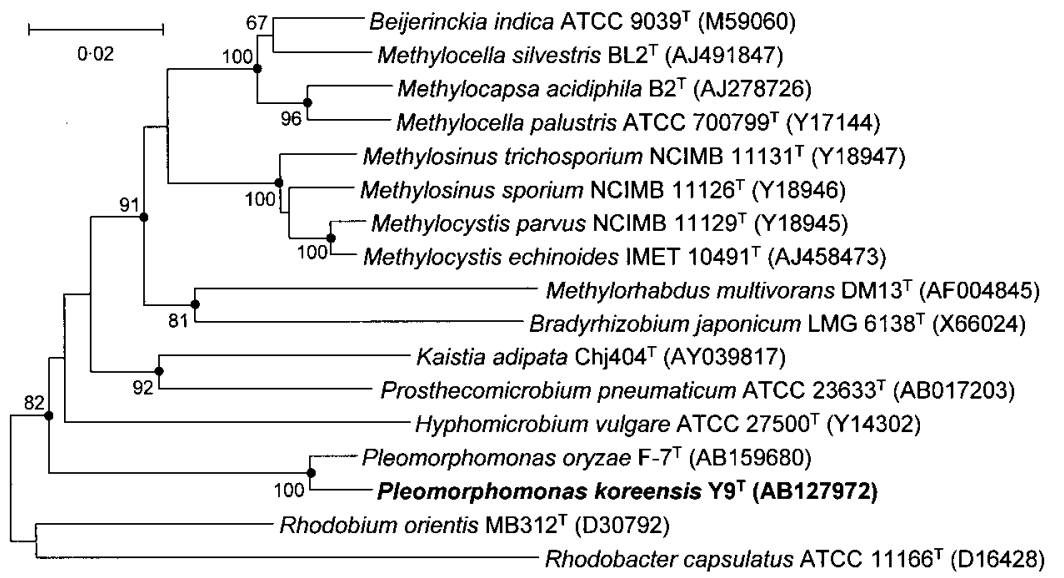

Fig. 1. Neighbour-joining tree, based on 16S rRNA gene sequences, showing the phylogenetic positions of strain $\mathrm{Y}^{\top}$ and related taxa. Filled circles at nodes indicate generic branches that were also recovered by using maximum-parsimony algorithms. Bootstrap values (expressed as percentages of 1000 replications) greater than $65 \%$ are shown at the branch points. Bar, 0.02 substitutions per nucleotide position.

oryzae $\mathrm{F}-7^{\mathrm{T}}(98 \cdot 5 \%)$. Lower levels of similarity $(<92 \cdot 5 \%)$ were found with respect to all available sequences of species of the Rhizobiales with validly published names. This relationship between strain $\mathrm{Y}^{\mathrm{T}}$ and other members of the order Rhizobiales was also evident in the phylogenetic tree (Fig. 1). Strain $\mathrm{Yg}^{\mathrm{T}}$ and P. oryzae formed a monophyletic clade with a high bootstrap value $(100 \%)$ that was supported by both types of tree-making method employed in this study.

Ubiquinone Q-10 was the predominant quinone in strain $\mathrm{Y} 9^{\mathrm{T}}$ and no menaquinones were detected. Strain $\mathrm{Y} 9^{\mathrm{T}}$ had a cellular fatty acid profile that contained large amounts of

Table 2. Cellular fatty acid profiles of strain $Y 9^{\top}$ and $P$. oryzae strains

Data for P. oryzae are taken from Xie \& Yokota (2005). Fatty acids that account for less than $1 \%$ of the total fatty acids are not shown, so the percentages do not add up to $100 \%$. For unsaturated fatty acids, the position of the double bond is located by counting from the methyl $(\omega)$ end of the carbon chain; cis and trans isomers are indicated by the suffixes $c$ and $t$, respectively.

\begin{tabular}{|lcc|}
\hline Fatty acid & Strain $\mathbf{Y 9}^{\mathrm{T}}$ & P. oryzae \\
\hline Saturated fatty acids & & \\
$\mathrm{C}_{16: 0}$ & $13 \cdot 3$ & $12 \cdot 0-15 \cdot 3$ \\
$\mathrm{C}_{18: 0}$ & $3 \cdot 3$ & $3 \cdot 6-7 \cdot 9$ \\
$\mathrm{C}_{19: 0}$ cyclo $\omega 8 c$ & $11 \cdot 8$ & $27 \cdot 9-52 \cdot 7$ \\
Unsaturated fatty acids & & \\
$11-$ Methyl $\mathrm{C}_{18: 1} \omega 7 c$ & - & $1 \cdot 8-3 \cdot 1$ \\
$\mathrm{C}_{20: 2} \omega 6,9 c$ & - & $1 \cdot 2-1 \cdot 9$ \\
Hydroxy fatty acid & & \\
$\mathrm{C}_{18: 0} 3-\mathrm{OH}$ & - & $2 \cdot 2-2 \cdot 9$ \\
Summed features & & \\
SF3 & $8 \cdot 1$ & $2 \cdot 9-3 \cdot 0$ \\
SF7 & $63 \cdot 5$ & $11 \cdot 0-36 \cdot 7$ \\
\hline
\end{tabular}

${ }^{*}$ Summed features are groups of two or three fatty acids that cannot be separated by GLC with the MIDI system. SF3, $\mathrm{C}_{14: 0} 3-\mathrm{OH}$ and/or $\mathrm{C}_{16: 1}$ iso I; SF7, $\mathrm{C}_{18: 1} \omega 7 c / \omega 9 t / \omega 12 t$. saturated, unsaturated and cyclo fatty acids. The fatty acid profile of strain $\mathrm{Y}^{\mathrm{T}}$ comprised $\mathrm{C}_{18: 1} \omega 7 \mathrm{c} / \omega 9 t / \omega 12 t(63 \cdot 5 \%)$, $\mathrm{C}_{16: 0}(13 \cdot 3 \%), \mathrm{C}_{19: 0}$ cyclo $\omega 8 c(11 \cdot 8 \%), \mathrm{C}_{14: 0} 3-\mathrm{OH} / \mathrm{C}_{16: 1}$ iso $(8 \cdot 1 \%)$ and $\mathrm{C}_{18: 0}(3 \cdot 3 \%)$ (Table 2). At first sight, the two species appeared to have very different fatty acid profiles. However, the sum of the total amount of $\mathrm{C}_{19: 0}$ cyclo $\omega 8 c$ and $\mathrm{C}_{18: 1} \omega 7 c / \omega 9 t / \omega 12 t$, which are interconvertible, was similar. The $\mathrm{G}+\mathrm{C}$ content of the genomic DNA of strain $\mathrm{Y}^{\mathrm{T}}$ was $65 \cdot 1 \mathrm{~mol} \%$. The phylogenetic, phenotypic and chemotaxonomic results described in this study support classification of strain $\mathrm{Y}^{\mathrm{T}}$ within the genus Pleomorphomonas (Xie \& Yokota, 2005).

Strain $\mathrm{Y}^{\mathrm{T}}$ showed $98.5 \% 16 \mathrm{~S}$ rRNA gene sequence similarity with respect to the type strain $\left(\mathrm{F}-7^{\mathrm{T}}\right)$ of $P$. oryzae. Where the level of 16S rRNA gene sequence similarity is greater than $97 \%$, a DNA-DNA hybridization relatedness of $70 \%$ plays an important role in clarifying the intergenetic relationship between species (Stackebrandt \& Goebel, 1994). Strain $\mathrm{Y}^{\mathrm{T}}$ exhibited $<29 \%$ DNA-DNA relatedness with the type strain of $P$. oryzae. This level is sufficiently low to permit the classification of strain $\mathrm{Y}^{\mathrm{T}}$ in a distinct species with respect to previously described type strains (Wayne et al., 1987).

On the basis of morphological, physiological and chemotaxonomic characteristics, together with data from the $16 \mathrm{~S}$ rRNA gene sequence comparisons described above, strain $\mathrm{Y} 9^{\mathrm{T}}$ should be placed within a novel species, for which we propose the name Pleomorphomonas koreensis sp. nov.

\section{Description of Pleomorphomonas koreensis sp. nov.}

Pleomorphomonas koreensis (ko.re.en'sis. N.L. fem. adj. koreensis pertaining to Korea, where the type strain was isolated and researched).

Cells are Gram-negative, oxidase-positive showing an oxidative metabolism, catalase-positive, non-spore-forming, non-motile rods, $0 \cdot 3-0 \cdot 5 \mu \mathrm{m}$ in diameter and $1 \cdot 5-3 \cdot 0 \mu \mathrm{m}$ in length. Growth occurs on R2A agar, nutrient agar and trypticase soy agar at $30^{\circ} \mathrm{C}$ and $\mathrm{pH} 6 \cdot 0-8 \cdot 0$. Able to 
assimilate L-fucose, $\mathrm{N}$-acetylglucosamine and D-melibiose as sole carbon sources. Unable to assimilate 4-hydroxybutylate, caprate, valerate, adipate, suberate, glycogen, 5ketogluconate or 2-ketogluconate as sole carbon sources. Other substrate-utilization data and details of enzyme production, acid production and physiological characteristics are indicated in Table 1. Predominant quinone is $\mathrm{Q}-$ 10. Fatty acids consist largely of $\mathrm{C}_{18: 1}, \mathrm{C}_{16: 0}$ and $\mathrm{C}_{19: 0}$ cyclo $\omega 8 c$. The $\mathrm{G}+\mathrm{C}$ content of the genomic DNA of the type strain is $65 \cdot 1 \mathrm{~mol} \%$ (determined by HPLC).

The type strain, $\mathrm{Y9}^{\mathrm{T}}\left(=\mathrm{KCTC} 12246^{\mathrm{T}}=\mathrm{NBRC} 100803^{\mathrm{T}}\right)$, was isolated from a contaminated culture of Rhodopseudomonas palustris in Daejeon, Korea.

\section{Acknowledgements}

This work was supported by the 2005 Agricultural R\&D Promotion Center Program, Ministry of Agriculture and Forestry, Republic of Korea.

\section{References}

Buck, J. D. (1982). Nonstaining (KOH) method for determination of Gram reactions of marine bacteria. Appl Environ Microbiol 44, 992-993.

Cappuccino, J. G. \& Sherman, N. (2002). Microbiology: a Laboratory Manual, 6th edn. Menlo Park, CA: Benjamin Cummings Science Publishing.

Ezaki, T., Hashimoto, Y. \& Yabuuchi, E. (1989). Fluorometric deoxyribonucleic acid-deoxyribonucleic acid hybridization in microdilution wells as an alternative to membrane filter hybridization in which radioisotopes are used to determine genetic relatedness among bacterial strains. Int J Syst Bacteriol 39, 224-229.

Felsenstein, J. (1985). Confidence limit on phylogenies: an approach using the bootstrap. Evolution 39, 783-791.

Fitch, W. M. (1972). Toward defining the course of evolution: minimum change for a specific tree topology. Syst Zool 20, 406-416.

Garrity, G. M. \& Holt, J. G. (2001). The road map to the Manual. In Bergey's Manual of Systematic Bacteriology, 2nd edn, vol. 1, pp. 119-166. Edited by G. M. Garrity, D. R. Boone \& R. W. Castenholz. New York: Springer.

Hall, T. A. (1999). BioEdit: a user-friendly biological sequence alignment editor and analysis program for Windows 95/98/NT. Nucleic Acids Symp Ser 41, 95-98.

Kim, M. K., Im, W.-T., Ohta, H., Lee, M. \& Lee, S.-T. (2005). Sphingopyxis granuli sp. nov., a $\beta$-glucosidase producing bacterium in the family Sphingomonadaceae in $\alpha-4$ subclass of the Proteobacteria. J Microbiol 43, 152-157.

Kimura, M. (1983). The Neutral Theory of Molecular Evolution. Cambridge: Cambridge University Press.

Kumar, S., Tamura, K. \& Nei, M. (2004). MEGA3: integrated software for molecular evolutionary genetics analysis and sequence alignment. Brief Bioinform 5, 150-163.

Mesbah, M., Premachandran, U. \& Whitman, W. B. (1989). Precise measurement of the $\mathrm{G}+\mathrm{C}$ content of deoxyribonucleic acid by highperformance liquid chromatography. Int J Syst Bacteriol 39, 159-167.

Poly, F., Monrozier, L. J. \& Bally, R. (2001). Improvement in the RFLP procedure for studying the diversity of nifH genes in communities of nitrogen fixers in soil. Res Microbiol 152, 95-103.

Saitou, N. \& Nei, M. (1987). The neighbor-joining method: a new method for reconstructing phylogenetic trees. Mol Biol Evol 4, 406-425.

Sasser, M. (1990). Identification of bacteria by gas chromatography of cellular fatty acids. MIDI Technical Note 101. Newark, DE: MIDI.

Shin, Y. K., Lee, J.-S., Chun, C. O., Kim, H.-J. \& Park, Y.-H. (1996). Isoprenoid quinone profiles of the Leclercia adecarboxylata KCTC $1036^{\mathrm{T}}$. J Microbiol Biotechnol 6, 68-69.

Stackebrandt, E. \& Goebel, B. M. (1994). Taxonomic note: a place for DNA-DNA reassociation and $16 \mathrm{~S}$ rRNA sequence analysis in the present species definition in bacteriology. Int J Syst Bacteriol 44, 846-849.

Thompson, J. D., Gibson, T. J., Plewniak, F., Jeanmougin, F. \& Higgins, D. G. (1997). The CLUSTAL_X windows interface: flexible strategies for multiple sequence alignment aided by quality analysis tools. Nucleic Acids Res 25, 4876-4882.

Wayne, L. G., Brenner, D. J., Colwell, R. R. \& 9 other authors (1987). International Committee on Systematic Bacteriology. Report of the ad hoc committee on reconciliation of approaches to bacterial systematics. Int J Syst Bacteriol 37, 463-464.

Xie, C.-H. \& Yokota, A. (2005). Pleomorphomonas oryzae gen. nov., sp. nov., a nitrogen-fixing bacterium isolated from paddy soil of Oryza sativa. Int J Syst Evol Microbiol 55, 1223-1237. 